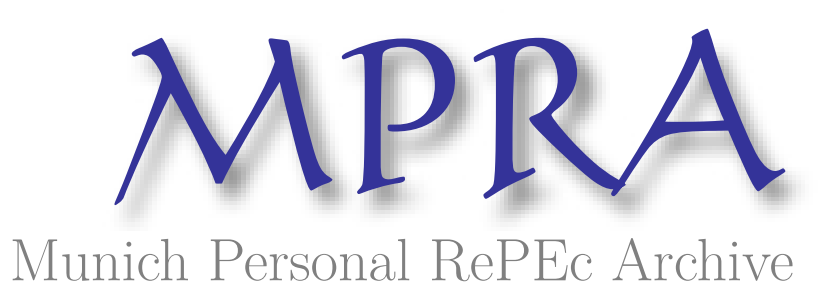

\title{
Application of Discounted Cash Flow Model Valuation - Wal-Mart
}

Tan, Zekuang

26 December 2016

Online at https://mpra.ub.uni-muenchen.de/83903/

MPRA Paper No. 83903, posted 12 Jan 2018 13:04 UTC 

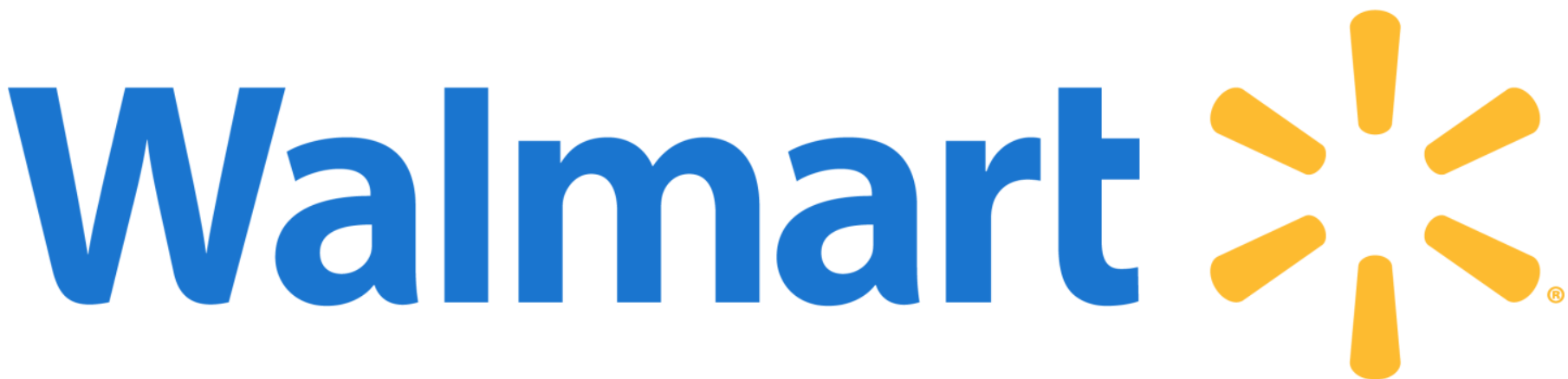

Application of Discounted Cash Flow Model Valuation - Wal-Mart

Zekuang Tan (Tyson) 


\begin{abstract}
The objective of this research paper is to examine if DCF models offer reliable and accurate valuations of Wal-Mart. With the purpose of achieving most accurate results, an efficient combination between theory and practice was implemented throughout the valuation. The DCF valuation of free cash flow to equity holders was performed and the stock price of Wal-Mart was suggested it to be $\$ 81.63$. Afterwards, we tracked the six-month stock price movement of Wal-Mart, (from 2016 Jan to 2017 Jun) and surprisingly found that the price had climbed from $\$ 69.24$ to $\$ 80.47$.
\end{abstract}

\title{
INTRODUCTION
}

Wal-Mart Stores Inc. (WMT) is the world's largest retailer and grocery chain by sales. Incorporated in 1969, WMT currently employs 2.3 million global employees to operate 11,528 stores in 28 countries and had revenues exceeding $\$ 485$ billion in 2016. The company has focused its establishment on a cost-leadership strategy; leveraging its large scale and sales numbers to make up for smaller profit margins. The company operates three separate divisions including Wal-Mart International, Wal-Mart US and Sam's Club. The company operates supercenters, discount stores, warehouse clubs, neighborhood markets and retail websites, offers general merchandise and a full line of groceries with the U.S. as its main market. The following section will analyze the business environment of WMT using a top-down approach.

\section{MACROECONOMIC ANALYSIS}

World real GDP is expected to grow by $3.8 \%$ in 2017 and the increase in purchasing power of consumers has a high likelihood of being positive for WMT. Real GDP is further expected to grow by $2.7 \%$ in the US, which is the most important market. Nevertheless, given the global presence of the company, WMT is highly exposed to exchange rate risks. Fluctuations in currency exchange rates resulted in a net loss of $\$ 4.7$ billion for fiscal 2016, and the impact could become even greater due to the current appreciation of the US dollar. WMT does hedge partially against exchange rate fluctuations to reduce the risk. WMT also hedges a portion of its interest rate risk due to borrowings by entering into interest rate swaps. The steep yield curve suggests expectations for the current low rates to rise. The rise is based on Jan 31 2016, a 100-basis point increase 
would cause the annual interest rates for WMT to rise about $\$ 79$ million and a loss in value of their swaps of \$14 million.

\section{INDUSTRY ANALYSIS}

The global retail industry has been growing at a rate of $5 \%$ in recent years, and this trend is forecasted to continue mainly due to an increase in GDP and disposable income in many developing countries (Marketline, 2016). WMT gets 59\% of revenue from the US retail market, where retail sales are expected to grow by $3 \%$ (IBID). These figures suggest that WMT could grow organically in the future. WMT operates mainly within the Warehouse Clubs and Supercenters industry that is highly concentrated, with a four-firm concentration of 92.1\%; Wal-Mart (68.6\%), Costco (17.1\%), Meiji Inc. (3.5\%), and Target (2.9\%) in 2016. The highly competitive industry is characterized by an oligopolistic market structure. The major players typically compete with strong brands and successful business models, but they are especially vulnerable to price wars. Recent trends in food deflation and growth of online retailing with a more flexible cost structure have contributed to increased competition. WMT's recent price slashing move, dropping grocery prices by $10 \%$, is expected to threaten a potential collective loss of $\$ 35$ billion in revenue for the main competitors (SOURCE). This would imply lower margins for all retailers while a lack of retaliation could further imply loss of market share to WMT.

The industry is characterized by limited product differentiation and very low switching costs, which to some extent increases the buyer power. This leads to high buyer mobility, which further forces large retailers to have attractive pricing schemes (Marketline, 2015). Entry costs are high, as entrants may struggle with the aggressive marketing and pricing of the current players due to economies of scale. WMT has substantial bargaining power over suppliers considering the size of the company and the backward integration with its own line of brands. WMT also makes its suppliers responsible for its Gross Margin Return on Inventory Investment and underperforming suppliers can easily be replaced.

In terms of substitutes, E-commerce retailing is emerging and traditional retailers are facing increasing competition from online companies, such as Amazon. WMT invested \$296 million in e-commerce initiates in 2016, and the company currently has 16 websites in 11 countries (Annual report, 2016). However, WMT's 
online sales of $\$ 13.5$ billion in 2016 are way below Amazon's sales of $\$ 82.8$ billion. Online sales growth of WMT is further just $7 \%$ in 2016, which is below the $23 \%$ online growth rate of Target and even below the industry average of $15.1 \%$ (Wahba, 2016). This is a concern for WMT, as global E-commerce retail sales are expected to rise $220 \%$ from 2015 to 2019 (Statista, 2015).

\section{BUSINESS STRATEGY ANALYSIS}

WMT has several competitive advantages that enable the company to be a cost leader. Firstly, their large scale allows them to enjoy significant cost savings from economies of scale. The company is further able to keep costs low due to an efficient distribution network. WMT operates 313 distribution facilities globally, which ensures a large product portfolio that is distributed in the most efficient manner (Marketline, 2016). Technological knowledge and the utilization of information systems is further a competitive advantage that increases the efficiency and decreases costs in distribution. WMT's data collection and auto-replenishment system help WMT and its partner suppliers to more effectively predict customer demand, which help to maximize store sales productivity at a lower cost (IBID). WMT's extensive marketing activities such as the "Everyday Low Prices" campaign, has increased the brand awareness and attracting a large and loyal customer base. The brand has thus become a very important asset for the company.

\section{ACCOUNTING DISTORTIONS}

As a result of the limitations of GAAP, the value of WMT's brand is not reflected on the Balance Sheet. Strong brand image and WMT membership-based warehouse club can drive revenue from loyal customers but these values remain missing from the asset side on Balance Sheet. ROE is thus overstated compared to the true economic rate of return, with the economic value of brand equity and comprehensive customer database reflected in Income Statement but the balance sheet remains permanently conservative. The company also leverages house brands to sell its own products including Sam's Choice (premium foods with organic ingredients), Great Value (low-priced household consumables) and many more. The house brands generate economic value for the company by a form of vertical integration, where it can act as both supplier and retailer e.g. WMT is able to sell products under its Great Value brand at a lower cost than name-brand products, yet with better margins, resulting in a higher Revenue/COGS in the income statement. A higher 
Net Income in the Income Statement reflects this. The assets are however not accounted for in the balance sheet as almost all of the house brands have been created by WMT and not acquired, in which case some of the brand value would have been reflected in Goodwill.

One of the main competitive advantages of WMT is their ability to efficiently manage inventory. This is largely achieved through the use of WMT's Retail Link, a program that gives suppliers the data they need to adjust supply after demand as precise as on an hourly basis. Leveraging the use of data this way implies WMT could tie up less cash in inventories, resulting in less need for financing. From an accounting perspective, this implies either a lower need for debt and hence lower interest expense, or a lower need for issuance of common equity. The former would increase ROE by increasing Net Income to Common Equity, and the latter would do the same through implying less Common Equity on the balance sheet. In either way ROE is overstated compared to the economic rate of return.

We further identified a nonrecurring item on the Income Statement. In fiscal 2016, WMT purchased the remaining shares of Yihaodian, its Chinese e-commerce platform, from non-controlling interests. WMT paid approx. $\$ 760$ million in cash. No revaluation of the Yihaodian was made in conjunction with this purchase and hence it had no effect on income, and we did not need to adjust for it.

\section{FINANCIAL RATIO ANALYSIS - DECOMPOSITION OF ROE}

Wal-Mart's ROE fell by $12.6 \%$ YOY in 2016 and to analyze the driving factors behind this change, we look into the advanced Dupont model in eVal. Specifically, RNOA fell by $-7.3 \%$; LEV fell by $-13.3 \%$; while spread fell by $-11.3 \%$. Change in RNOA is further decomposed into change in Net Operating Asset Turnover $(+2.3 \%)$ and Net Operating Margin (-9.5\%). The loss in profitability more than offsets the slight gain in asset efficiency. Upon further analysis of the Income Statement, we find that the $4.16 \%$ increase in SG\&A is the most significant driver for the fall in profitability. We then analyze the trend in SG\&A/Sales for the past years and find that the ratio increases consistently from $19.0 \%$ in 2013 to $20.3 \%$ in 2016. For FY2016, the 91 basis point increase was primarily due to (i) an increase in wage expense at the Wal-Mart U.S. segment and (ii) $\$ 0.9$ billion charge for the store closures and (iii) the continued investments in Digital Retail and IT. 
We believe the higher operating expenses are not necessarily a red flag for WMT. Firstly, WMT has affirmed their position as a "growth company", with FY2016 "being another year of foundational investment" (Annual Report, 2016), The closure of underperforming stores could thus be a sound economic decision to improve overall cost efficiency going forward rather than an indication of losing market share. Secondly, the continued investment in digital retail supports WMT plans to increase their market share in ecommerce. WMT has seen $+107 \%$ growth in global e-commerce net sales over the past 4 years but the strong growth of Amazon Prime could pose a threat to WMT in online retailing. Thirdly, the move towards competitive pay is a reflection of WMT's commitment to investing in their associates, which could yield favorable returns in the future due to increase in productivity.

The change in LEV is largely attributed to the $-8.9 \%$ decrease in Net Financial Obligation (NFO), which could be broken down into a $-10 \%$ fall in short term debt, $-6 \%$ in long-term debt and $-33 \%$ in Minority Interest (which is due to WMT completing the purchase of all of the remaining non-controlling interest in Yihaodian to increase their e-commerce operations in China in July 2015). For FY2016, the increase in net cash flows provided by short-term borrowings for WMT partially offset a larger $\$ 2.0$ billion decrease in long-term debt due within one year. The slight 1.6\% increase in Net Borrowing Cost (NBC) suggests WMT is probably paying down debts with lower interest rate. The interest rate expense is thus expected to be higher in the coming years.

\section{SUSTAINABILITY OF CURRENT PROFITABILITY}

While the evolving competitive environment is likely to put pressure on WMT's margins, there are good reasons to be optimistic about WMT's future profitability considering their large scale, dominant market position and their general resilience to swings in economic cycles. Their loss in profitability in the current fiscal year should be interpreted as temporary restructuring costs to enhance future performance as well as investment required to expand their market share both offline and online. Lower margins due to price slashing in the short-run could favor WMT's dominant market leadership going forward. Their healthy liquidity and solvency ratios (to be discussed later) could provide a buffer for the adverse impact of lower margins in the short-run. Their conservative accounting, relatively low financial leverage as well as decisions 
to eliminate less cost-efficient stores and increased investment in human resource do bode well for WMT's future. We believe that WMT's long-term growth and profitability is contingent on their success in penetrating emerging markets as well as their relative performance against Amazon Inc., as we expect a blurring of lines between online and offline retailing going forward.

\section{CASHFLOW ANALYSIS}

The reformatted CF statement illustrates that Wal-Mart is able to generate cash from its operations. In 2016 WMT generated an impressive \$29.1 billion in cash from operations and their positive cash flow from working capital help ensure WMT can meet short-term debt and upcoming operational expenses. WMT invested significantly in growth in 2016, with CAPEX of \$11.6bn being larger than depreciation expense of \$9.5bn. Increasing capital assets supports WMT's business strategy to increase market penetration and enter new emerging markets. The strategy of increasing growth through e-commerce further requires substantial capital investments. Nevertheless, internally generated cash mainly financed these investments, as WMT is less dependent on external financing. WMT's relatively low financial leverage is revealed by their low Debtto-Equity ratio of only 0.56 . WMT has $\$ 18.4 \mathrm{bn}$ free cash flow to debt and equity, of which WMT paid $\$ 1.7 \mathrm{bn}$ in after tax interest expense and repaid $\$ 5.7 \mathrm{bn}$ of debt. WMT's financial strength allowed for shareholder returns in excess of $\$ 10 \mathrm{bn}$ through dividends $(\$ 6.2 \mathrm{bn})$ and share repurchases $(\$ 4.1 \mathrm{bn})$. These decisions resulted in a net decrease of the cash balance of $\$ 430$ million. While WMT's relatively aggressive share repurchase program may cause their relatively low financial leverage to edge up marginally, we believe that WMT's ability to generate consistent strong free cash flows will continue to provide stability to its credit risk profile. The Funds Flow Coverage Ratio for WMT is 13.6, which further supports our view that WMT is able to meet its financial obligations comfortably and is less reliant on external financing. This is also consistent with Moody's affirmation of stable outlook for WMT, giving Aa2 senior unsecured and Prime-1 commercial paper ratings (Oct 2015).

\section{COMPETITOR COMPARISON}

The three close competitors selected for peer group analysis are: Costco (COS), Target Corp (TGT) and Amazon (AMZN). COS is an American membership-only warehouse club that provides a wide selection of 
merchandise and TGT is the second largest discount retailer in U.S. behind WMT. COS and TGT are similar to WMT in relative size and they too compete on a high volume, low cost strategy selling groceries and nongrocery consumer items with U.S. as their main market. However, Costco is more similar to WMT Sam's Club due to their exclusive focus on membership. TGT is smaller and caters to slightly more affluent customers, offering more quality brands but with less variety. While AMZN, an American e-commerce and cloud computing company, has a very different structure compared to the brick-and-mortar discount chain, WMT's push into the online market makes AMZN a potentially relevant competitor due to their established dominance in digital retailing.

Table 2 in the appendices provides an overview of key profitability and risk ratios. While WMT's negative sales growth $(-0.7 \%)$ pale in comparison to AMZN's impressive $20.2 \%$ top line growth, WMT has a healthier adjusted Net Operating margin of 3.5\% compared to the negligible $0.7 \%$ margin in AMZN and $2.1 \%$ margin in COS. While TGT outperforms in terms of sales growth and net operating margins, they have the lowest inventory turnover with an average inventory-holding period of about 2 months, compared to about 1.5 month in WMT. In contrast to the high D/E ratio of TGT, WMT has the least financial leverage with D/E ratio of only 0.558 . This partially contributes to WMT having the lowest ROE of $18.1 \%$ among the offline discount chains, with COS having $20.7 \%$ and TGT offering 25\%. Another factor is WMT's lower asset efficiency of $12.8 \%$ RNOA compared to COS'14.2\% and TGT's $14.4 \%$. WMT has an EBITDA Interest Coverage ratio of 13.6, which is close to $12.1 \%$ in TGT. COS has an impressive EBITDA Interest Coverage of 64.2 and that is due to their much lower interest expense (and lower debt levels). The short-term liquidity of the three companies can be considered reasonably decent.

\section{VALUATION ASSUMPTIONS}

The revenue forecast in eVal suggests a revenue decrease of $-0.7 \%$, mimicking fiscal 2016 before trending it towards the long-term growth rate. However, taking into consideration the significant appreciation of the USD against foreign currencies, visible in figure 1 in the appendix, it is clear that currency exchange rates has had an impact on revenue, as $41 \%$ of WMT's revenue comes from outside the US. On a constant currency basis, WMT sales increased by $2.8 \%$. As the dollar index has remained relatively in line with the 
previous year during fiscal 2017, we thus expect the impact from foreign exchange on fiscal 2017 overall to be neutral, allowing for a positive overall revenue growth. To quantify this, revenue has been broken down into U.S., International, and Sam's Club segment sales. Growth from increase in of stores and growth from same-store sales increase was then analyzed separately. For same-store sales (SSS), the Q3 press release offered estimates guidance for the U.S. and Sam's Club segments (1.25\% each), whilst the International segment's SSS growth in Q4 was estimated to follow the past five quarters' trend. Although still implying a decrease QoQ, it is becoming less negative each quarter, reaching -3.1\% in Q4. See table 3 in appendix for details. Growth from the opening of new stores was based on the net number of stores WMT has left to open in Q4 in order to meet its full year guidance on new store openings taking into account how many were opened Q1-Q3. This guidance was deemed reasonable by comparing how many net stores was opened Q1Q3 to the initial guidance, and how store openings had been distributed across the year previous fiscal years. Notably, Q4 store openings have historically come in larger amounts than those of other quarters, and in fiscal Q4 fiscal 2017 a net of 150 stores are estimated to be added. The growth will exclusively come from the U.S, where 170 new stores are anticipated while the International segment is expected to continue to shrink by 20 stores net. We did not conduct a separate analysis for E-commerce sales due to a lack of available data, but considering that WMT's E-commerce sales was less than $1 \%$ of total sales in 2016, these are yet not material enough to call for a separate forecast.

\section{COGS}

While the global food deflation may lower COGS for WMT, we believe that this trend is likely to hurt WMT's topline to a greater extent, resulting in lower margins. Instead of simply passing cost savings to the customers, we expect the company to ramp up its aggressive pricing efforts in an attempt to force out less efficient mega-retailers in a consolidating industry. The ratio of COGS to revenue is expected to rise in the coming two years as a result of WMT's strategic move. We anticipate the aggressive slashing of prices to increase COGS/Revenue the coming two fiscal years before the effects of the campaign bears fruit in increased market share, lower competition and room to adjust prices to resume the COGS/Revenue to $72.9 \%$ achieved during fiscal 2016.

\section{SG\&A}


SG\&A/Revenue has increased during Q2-Q3 fiscal 2017 as part of a 2-year investment in higher U.S. hourly wages, education and training. The effect is visible in the quarterly statements, and forecasted SG\&A/Revenue for Q4 has thus been adjusted upwards to the average ratio of SG\&A to Sales in Q3 and Q4, resulting in a $1.1 \%$ increase.

\section{Effective Tax Rate}

The effective tax rate saw a deviation from a neutral trend fiscal 2016, where an item described as "Other, net" in the tax footnotes had a $-2.6 \%$ impact on ETR. With no apparent explanation to what exactly caused this deviation, it is assumed to be a one-time item, which will not affect the ETR going forward. ETR was thus estimated as the average of the last three years prior to fiscal 2016.

\section{CAPEX}

For CAPEX, the fiscal 2016 AR guidance does not look as reliable at a first look. Comparing the first 9 months of the fiscal 2017 with 2016, CAPEX has decreased 9.29\%, suggesting a full year CAPEX of $\$ 10.4 \mathrm{bn}$ if the trend continues. However, the $\$ 11.1 \mathrm{bn}$ CAPEX guidance from 2016 AR may very well be justifiable since we expect a relatively large number of new stores to open in the U.S. segment (170), compared to the net closures of stores Q4 fiscal $2016(-57)$. With this in mind, CAPEX is estimated to be \$11.1bn for the full year.

\section{Depreciation}

The last three years has seen depreciation steadily growing while CAPEX has decreased, however, the effect of lower CAPEX is visible in a slower growth of depreciation. To forecast depreciation, the ratio of depreciation to CAPEX was thus calculated, and its YoY trend assessed. Assuming that depreciation over CAPEX would grow in line with the last two years, the full year depreciation for fiscal 2017 was forecasted at $\$ 9962 \mathrm{bn}$, an increase of $5.4 \%$. In practice this is a result of continued high depreciation of capital assets stemming from the Corporate \& support segment, which is seemingly unaffected by decreased CAPEX.

\section{PP\&E}

PP\&E was calculated as PP\&E previous year adding CAPEX and less depreciation.

\section{Long-Term Debt}


During fiscal 2017, \$1,519bn of long-term debt will become current, and \$135m of new long-term debt has been issued. No major long-term debt issuance is scheduled for Q4 fiscal 2017, and the long-term debt for the full year is hence estimated to decrease by $\$ 1,384 \mathrm{bn}$.

\section{Financial Leverage}

With the acquisition of the remaining shares of Yihaodian, and debt repayments outweighing share buybacks in the short-term, our forecasts yield just a slightly lower financial leverage (NFO/Common Equity) for the coming years. However, as share repurchases increase, the trend is expected to turn and move to increasing leverage to grow more in line with the historical average.

\section{DCF VALUATION OUTCOME}

A DCF valuation of free cash flow to equity holders was performed. When determining the cost of equity, WMT's raw beta was found to be around 0.55 , which despite the positive effect of low correlation with the market from an investor perspective was deemed too low for market price based valuation purposes. Instead, the adjusted 2Y Weekly beta one standard error above the estimated mean was chosen. One consideration in favor of this choice is that the S\&P500 the past years may have an unusually low correlation to WMT given how energy stocks, which have an impact on the index, have been driven by the unusually high volatility in the price of oil. Using the Damodaran's latest country-specific equity risk premium, the cost of equity was determined to be $7.27 \%$, yielding a price per share of $\$ 81.63$. We therefore recommend buying WMT stock at today's (18 Nov) price of $\$ 68.54$.

\section{Sensitivity Analysis}

A sensitivity analysis of the LTGR plotted against the Cost of Equity shows a very wide share price range of \$56.29 - \$171.55, allowing for a $1 \%$ deviation in the long-term growth initially set at $1.97 \%$, and a $2 \%$ deviation in the cost of equity where our base case is $7.27 \%$. However, the range does favor a buy rather than sell. Another important driver for the WMT stock price in our model is the SG\&A and COGS as a percentage of revenue. With no R\&D costs recorded separately, this is the company's EBITDA Margin. From a sensitivity analysis plotting the long-term EBITDA Margin against long-term growth rate, it is evident that the share price range indeed favors a buy. A long-term EBITDA margin of $7.7 \%$ as was the case 
prior to 2014 yields a share price of $\$ 92.62$ keeping long-term growth constant at $1.97 \%$. Only in the lowgrowth, low-margin scenario does the model yield a stock price lower than that of 18 Nov 2016.

\section{Conclusion \& Recommendation}

The recommendation for the WMT stock is a simple purchase. Regarding the apparent challenges in increased competition and lower margins, the advance of E-commerce, and uncertainty about the future of brick-and-mortar stores, there are few retailers better positioned to adapt such new competitive environments. With a strategy already in place for such adaptation and attractive stock price DCF-valuation perspective, WMT stock is a clear buy.

Afterwards, we tracked the six-month stock price movement of Wal-Mart (from 2016 Jan to 2017 Jun) and surprisingly found that the price climbed from $\$ 69.24$ to $\$ 80.47$. It is very close to our prediction ( $\$ 81.63$ ). We conclude that DCF models offer reliable valuation of Wal-Mart. 


\section{BIBLIOGRAPHY}

- IBISWorld. (2016, May). Warehouse Clubs \& Supercenters in the US (45291). Retrieved November 20, 2016, from http://clients1.ibisworld.com/reports/us/industry/default.aspx?entid=1092

- MARKETLINE 1, (2016, March 25), Wal-Mart Store Inc. [company profile]. Retrieved November 13, 2016, from MarketLine Advantage database.

- MARKETLINE 2. (2016, August). Global Food Retail [industry profile]. Retrieved November 13, 2016, from MarketLine Advantage database.

- PETERSON, H. (2016, October 17), Wal-Mart's price cuts should terrify Target, Dollar General, and Family Dollar. Retrieved November 24, 2016, from http://uk.businessinsider.com/walmartprice-cuts-should-terrify-target-2016-10

- $\quad$ STATISTA 1, (2015) Retail e-commerce sales worldwide from 2014 to 2020 (in billion U.S. dollars), Retrieved November 23, 2016, from: https://www.statista.com/statistics/379046/worldwide-retail-e-commerce-sales/.

- STATISTA 2, (2016), Wal-Mart's net sales worldwide from 2008 to 2016, by division (in billion U.S. dollars), Retrieved November 23, 2016, from https://www.statista.com/statistics/269403/netsales-of-walmart-worldwide-by-division/.

- WAHBA, P. (2015, November 17), The Big Cloud Hanging Over Walmart's Improving Sales? Soft E-commerce Growth. Retrieved November 23, 2016, from http://fortune.com/2015/11/17/walmartecommerce/

- WAHBA, P. (2016, October 18), Walmart's Price Cuts Could Cost Target Billions of Dollars. Retrieved November 23, 2016, from http://fortune.com/2016/10/18/walmart-target-price-war/ 
- WAHBA, P. (2016, May 20), The Silver Lining In Walmart's Slowing E-Commerce Growth. Retrieved November 23, 2016, from http://fortune.com/2016/05/20/the-silver-lining-in-walmartsslowing-e-commerce-growth/

- WAL-MART. (2016). Annual report. Retrieved from http://s2.q4cdn.com/056532643/files/doc_financials/2016/annual/2016-Annual-Report-PDF.pdf

- WORLDBANK, (2016). Global Outlook. Disappointment, Risks, and Spillovers. Retrieved November 20, 2016, from: https://www.worldbank.org/content/dam/Worldbank/GEP/GEP2016a/Global-Economic-Prospects-January-2016-Global-Outlook.pdf 


\section{APPENDICES}

Table 1 - Reformatted Cash Flow Statement

Cash Flow Analysis - Wal-Mart

-Reformatting the CF Stmt **

\begin{tabular}{|c|c|}
\hline & (SMillions) \\
\hline 2016 & 2015 \\
\hline $15.080,0$ & $16.814,0$ \\
\hline & \\
\hline 1663,0 & 1515,3 \\
\hline & \\
\hline & \\
\hline $10.192,0$ & $9.455,0$ \\
\hline & 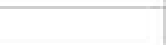 \\
\hline $26.935,0$ & $27.784,3$ \\
\hline $2,117,0$ & $2.295,0$ \\
\hline $29.052,0^{\circ}$ & $30.079,3$ \\
\hline & \\
\hline$(11.556,0)$ & $(12.366,0)$ \\
\hline 881,0 & $1.241,0$ \\
\hline $18.377,0$ & $18.954,3$ \\
\hline (1663.0) & $(1.515,3)$ \\
\hline$(5.716,0)$ & $(7.871 .0)$ \\
\hline & \\
\hline & \\
\hline $10.998,0$ & $9.568,0$ \\
\hline$(4.112,0)$ & $(1.015,0)$ \\
\hline & \\
\hline$(6.294,0)$ & $(6.185,0)$ \\
\hline$(1.022,0)$ & $(514,0)$ \\
\hline$-430,0$ & $1.854,0$ \\
\hline
\end{tabular}

Net increase (decrease) in cash balance 
Table 2 - Profitability and Risk Comparison

\begin{tabular}{|l|l|l|l|l|}
\hline FY2015 & WMT & COS & TGT & AMZN \\
\hline Sales Growth \% & -0.7 & 3.2 & 1.6 & 20.2 \\
\hline ROE & 0.181 & 0.207 & 0.250 & 0.049 \\
\hline RNOA & 0.128 & 0.142 & 0.144 & 0.033 \\
\hline Average Inventory Holding Period & 46.5 & 31.7 & 59.3 & 51.3 \\
\hline Debt-to-Equity & 0.558 & 0.580 & 0.985 & 0.867 \\
\hline Net Operating Margin (adjusted) & 0.035 & 0.021 & 0.051 & 0.007 \\
\hline EBITDA Interest Coverage & 13.6 & 64.2 & 12.1 & 19.3 \\
\hline
\end{tabular}

Figure 1 - USD Exchange Rate

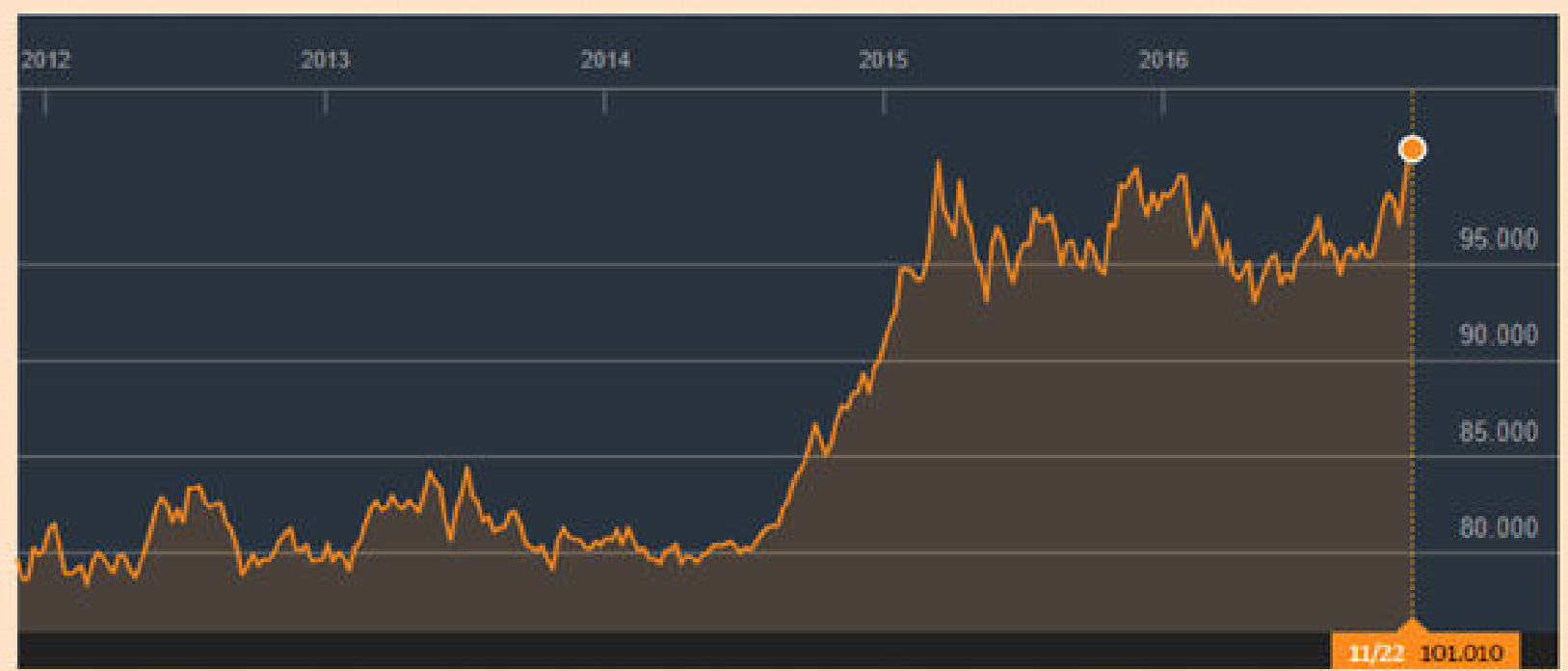


Table 3 - Revenue Assumptions and Forecast

\begin{tabular}{|c|c|c|c|c|}
\hline \multicolumn{5}{|c|}{ Revenue } \\
\hline New stores 2017, guidance from MD\&A & $\begin{array}{c}\text { Higher bound } \\
405\end{array}$ & $\begin{array}{c}\text { Lower bound } \\
342\end{array}$ & $\begin{array}{c}\text { Average } \\
374\end{array}$ & \\
\hline $\begin{array}{l}\text { New stores opened Q1-Q3 } \\
\text { Stores closed Q1-Q3 }\end{array}$ & $\begin{array}{l}\text { Q1 } \\
53 \\
54\end{array}$ & $\begin{array}{l}\text { Q2 } \\
61 \\
49\end{array}$ & $\begin{array}{c}\text { Q3 } \\
70 \\
16\end{array}$ & $\begin{array}{c}\text { Sum } \\
184 \\
119\end{array}$ \\
\hline Est. Stores Left to Open in 2017 & & 150 & & \\
\hline $\begin{array}{l}\text { Net new stores per segment Q1-Q3 fiscal } \\
2017 \\
\text { Forecasted new stores per segment in Q4 } \\
\text { Forecasted new stores per segment in Q4/2 } \\
\text { Average \$ million sales / store in Q4 2016 } \\
\text { Forecasted increase in sales from new } \\
\text { store openings }\end{array}$ & $\begin{array}{l}\text { US } \\
113,85 \% \\
170,58 \\
85,29 \\
\$ 17,81 \\
\$ 1.519\end{array}$ & $\begin{array}{r}\text { International } \\
-13,85 \% \\
-20,75 \\
-10,37 \\
\$ 5,19 \\
\\
\$-54\end{array}$ & $\begin{array}{r}\text { Sam's Club } \\
0,00 \% \\
0,00 \\
0,00 \\
\$ 21,59\end{array}$ & Sum \\
\hline $\begin{array}{l}\text { Number of stores end of Q3 fiscal } 2017 \\
\text { Average \$ million sales / store / segment in } \\
\text { Q4 fiscal } 2016 \\
\text { Comparable store sales revenue growth } \\
\text { forecast (Q3 press release) } \\
\text { Forecasted sales from current stores in Q4 } \\
\text { fiscal } 2017\end{array}$ & $\begin{array}{r}4648 \\
\quad \begin{array}{l} \\
\end{array} \\
\quad 17,81\end{array}$ & $\begin{array}{r}\text { International } \\
6289\end{array}$ & $\begin{array}{r}\text { Sam's Club } \\
656\end{array}$ & Sum \\
\hline Forecasted Q4 Total Sales / Segment & $\$ 85.334$ & $\$ 31.565$ & $\$ 14.338$ & $\$ 131.237$ \\
\hline
\end{tabular}

\begin{tabular}{|lrrr|r|r|}
\hline Full year forecast & \multicolumn{1}{c}{ Q1 } & \multicolumn{1}{c|}{ Q2 } & \multicolumn{1}{c|}{ Q3 } & \multicolumn{1}{c|}{ Q4 Forecast } & \multicolumn{1}{c|}{ Full year } \\
\hline Revenue from segments in fiscal & & & & & \\
2017 Q1-Q3 & $\$ 114.986$ & $\$ 119.405$ & $\$ 117.176$ & $\$ 131.237$ & $\$ 482.804$ \\
Revenue from membership fiscal & & & & & \\
2017 Q1-Q3 & $\$ 918$ & $\$ 1.449$ & $\$ 1.003$ & $\$ 1.255$ & $\$ 4.625$ \\
Membership \% of revenue & $0,80 \%$ & $1,21 \%$ & $0,86 \%$ & $0,96 \%$ & \\
\hline Total Forecasted Revenue Fiscal & & & & & $\$ \mathbf{\$ 4 8 7 . 4 2 8 . 2 5 7}$ \\
2017 (000's)
\end{tabular}

Table 4-COGS Assumptions and Forecast

\begin{tabular}{|ccccc|c|}
\hline \multicolumn{7}{|c|}{ COGS } \\
\hline & $\mathbf{2 0 1 6}$ & $\mathbf{2 0 1 7}$ & $\mathbf{2 0 1 8}$ & $\mathbf{2 0 1 9}$ and cont. & $\begin{array}{c}\text { Temp COGS/Revenue } \\
\text { increase from price } \\
\text { slashing }\end{array}$ \\
\hline COGS/Revenue & $73,21 \%$ & $73,21 \%$ & $73,21 \%$ & $72,91 \%$ & $0,30 \%$ \\
\hline
\end{tabular}


Table 5-CAPEX \& Depreciation Assumptions and Forecast

\begin{tabular}{|lrrrr|c|}
\hline \multicolumn{7}{|c|}{ CAPEX \& Depreciation (Million USD) } \\
\hline Item & $\mathbf{2 0 1 3}$ & $\mathbf{2 0 1 4}$ & $\mathbf{2 0 1 5}$ & $\mathbf{2 0 1 6}$ & $\mathbf{2 0 1 7}$ \\
CAPEX & 12.898 & 13.115 & 12.174 & 11.477 & 11.100 \\
Change in CAPEX & & $1,7 \%$ & $-7,2 \%$ & $-5,7 \%$ & $-3,3 \%$ \\
Depreciation & 8.478 & 8.870 & 9.173 & 9.454 & 9.962 \\
Depr \% of CAPEX & $65,7 \%$ & $67,6 \%$ & $75,3 \%$ & $82,4 \%$ & $89,7 \%$ \\
Change in Depr \% of CAPEX & & $1,9 \%$ & $7,7 \%$ & $7,0 \%$ & $7,4 \%$ \\
\hline
\end{tabular}

Table 6 - PP\&E Assumptions and Forecast

\begin{tabular}{|rrrr|}
\hline \multicolumn{4}{|c|}{ PP\&E } \\
\hline Ending 2016 & CAPEX Est & Depr Est & PP\&E Forecast \\
116.516 .000 & 11.100 & 9.962 & 116.517 .138 \\
\hline
\end{tabular}

Table 7 - Income Tax Expense Assumptions

\begin{tabular}{|l|l|}
\hline Income Tax Expense & Estimated to stay constant at average of last three years prior to fiscal 2016 \\
\hline
\end{tabular} where a significat change occurred

Table 8 - SG\&A/Sales Assumptions

SG\&A/Sales
Estmated to stay at average level of Q2-Q3 fiscal 2016 for two years and then trend back to historical average 